\title{
A Review on Key Performance Indicators for Measuring Real Estate Project Success
}

\author{
Alka Rani ${ }^{1 *}$, Rajwinder Singh ${ }^{1}$, Shilpa Taneja $^{2}$, Arun B. Prasad ${ }^{3}$, Sonia Dhiman ${ }^{1}$ \\ ${ }^{1}$ School of Management Studies, Punjabi University, Patiala 147002, India \\ ${ }^{2}$ Department of Business Administration, Chaudhary Devi Lal University, Sirsa (Haryana) 125055, India \\ ${ }^{3}$ Institute of Law, Nirma University, Ahmedabad 382481, India
}

Corresponding Author Email: alkabasu.ab@gmail.com

https://doi.org/10.18280/ijsdp.160420

Received: 16 December 2020

Accepted: 16 July 2021

\section{Keywords:}

real estate, construction sector, customer satisfaction, success factor, key performance indicators, budget, project management, scheduling

\begin{abstract}
The purpose of this study is to find numerous key performance indicators for measuring real estate project success. A Systematic literature review was adopted to achieve the research objective. The main objective of a systematic literature review is to identify, evaluate, and synthesize existing research. A total number of "82" papers from ABDC journals and other journals and conference papers, including thesis, book chapters, were used to identify all the success factors. The study reveals that most of the previous studies have considered threefactor cost, quality, and time, but a few factors have taken other success factors such as budget, schedule, client satisfaction, project manager competence. So there is a dire need to explore additional determinants as the real estate project success is influenced by several other variables. After the systematic literature review there are many other performance indicators such as customer satisfaction, budget, manager qualification and schedule are becoming important for good performance of construction project. The findings of the study have numerous suggestions and these implications are not only for the educational area but also for the construction sector. The study provides a direction for construction organizations and the researcher's future studies.
\end{abstract}

\section{INTRODUCTION}

The real estate industry attracts the most attention as compared to other industry and the construction sector plays a vital role in improving the fiscal development of any country [1-3]. The national budget is greatly affected by the performance of the construction industry. Infrastructure development is one of the main key tools for the financial development of a country. There is a dire need to improve the performance in the construction industries across the world economies. The purpose of the project management team is to achieve successful outcomes of the construction projects. The performance measures are considered as the important indicators in an organization that help identifying whether a process of activities undertaken or a progression of outputs achieves the organizational objectives.

In 2019, construction sector invested Rs 43,780 crore. The real estate sector directly employs sixteen percent of the workforce [4]. It will generate an increase in employment and growth of the economy in large numbers [5]. The construction sector creates a major contribution to employment. It is expected to be 30 percent higher than in the next era. In the present scenario's real estate sector, to achieve a competitive advantage over the firms, the success and efficiency of each project are required. Every business aims to achieve success and profit. The real estate sector is a project-based business and its success are determined by the project's success to a great extent. So, there's a need to discover the critical success aspect of the building industry [6]. The project is considered to be successful if it is completed in time, with a lesser cost and meets the quality requirements $[7,8]$. This is a traditional way of measuring the project success. By undertaking this research, we attempted to explore the other significant components that play a crucial role in the project success. Time, cost, and quality factors are the main factors for measuring project success. The study highlighted the seven indicators of project performance, namely: time, cost, quality, budget, schedule, client satisfaction, and project manager competency. Therefore, this study will provide future directions for the researchers and the real estate sector. Similarly, it will also help Real Estate developers, contractors for framing, and revising policies and strategies [9]. This study could help in improving their organizational performance regarding the ongoing projects. A number of key performance indicators (KPIs) were proposed in order to measure and evaluate the performance of the projects as well as the organizations in the construction industry. The performance can be measured by establishing KPIs and such KPIs provide objective criteria for measuring the project success [10]. The performance of a construction project has been assessed by the traditional factors such as time, cost and quality. With respect to the project success, majority of the studies have focused on time, cost, quality [11-16]. KPIs have been deliberated to reflect the worth of output or the outcomes related to the key aspects of a project. Some of the performance areas are common to the list, but there is no general consensus in the literature on the factors that need to be considered to measure the project success [12]. The review of the extant literature suggests that the performance evaluation of the construction projects has been gradually shifting beyond the traditional 
measures. The several researchers suggest that in addition to the iron triangle measures, but the customer satisfaction, budget, schedule, and the project manager's competence should also be considered as the performance evaluation criteria [17-28]. The buildings and infrastructure need to be evaluated based on their iron triangle, customer satisfaction, budget, schedule, and project manager competence for the overall success and well-being of their end users. Consequently, the future agenda of the project performance evaluation needs to be more comprehensive and should include not only the iron triangle, but the aforementioned variables such as customer satisfaction, budget, schedule, project manager's capability should be considered as criteria $[23,29,30]$. Based on the discussion above, the purpose of this research is to conduct a systematic investigation of the KPIs to measure the success of construction projects in order to contribute to apply understanding of effective and the successful ways of delivering such projects.

\subsection{Research gap}

Project Success Consists of Two Components (1) Project Management (2) Project Performance. A project can be successful when the project is completed within time, schedule, budget, good leadership skill and customer satisfaction. Project performance indicators specify the measurable evidence needed to prove that a project planned effort achieved the desired result.

The work of the Real Estate Sector is project-oriented. Most of the studies were carried out to determine the often referred to as the "Iron triangle" (cost, time, and quality). This research shall be exploring additional project success factors, which are helping various ongoing construction projects. With the help of these factors, risks can be reduced and it will also help in the success of the project. Therefore, apart from the 'iron triangle', the construction industry needs to pay special attention to success factors. Still the cost, time, and quality are most relevant to evaluate the organization's success [31]. When the project is completed on time, within cost, and quality and it is considered a successful construction project $[32,33]$. Its a traditional way to measure the project success. Through this research, we will explore the other important elements that play a significant role in project success. Time, cost, and quality factors are the main factor for the measure of project success. These studies consist of seven project performance indicators, namely: Time, cost, quality, budget, schedule, client satisfaction, and project manager competency. Therefore, this study will provide future direction for researchers and real estate sector [34]. To bridge this gap, the aims of this study to identify the Key Performance Indicators (KPIs) for measuring in the context of a construction project [35]. The review of the extant literature suggests that the performance evaluation of the construction projects has been gradually shifting beyond the traditional measures. The several researchers suggest that in addition to the iron triangle measures, but the customer satisfaction, budget, schedule, and the project manager's competence should also be considered as the performance evaluation criteria [16, 36, 37]. According to Toor et al. [35] The traditional project indicators of construction projects are iron triangles and that these indicators are not sufficient to measure performance. Other performance indicators such as customer satisfaction, budget, manager qualification and schedule are becoming important.

\subsection{Real estate sector}

The real estate sector is one of the developing areas worldwide. The organization's growth is one of the major tools for a country's financial growth, and this sector plays a chief contribution to the improvement of each country. The construction sector plays a vital role in improving the fiscal development of any country [38]. This sector has been ascended as one of the recognized areas at domestic as well as global level. The term 'Real Estate' is defined as property which includes buildings or structures over it. It can also include business houses like residential buildings, commercial offices, theatres, hotels and restaurants, industrial shops like retail shops, factories and government buildings. The Indian real estate sector has been witnessing some liveliness and positive market attitudes after reforming during the worldwide financial crisis over the years. A huge number of building projects were completed in India during the last decade [39]. The demand for the construction of residential houses is also coming on a large scale. Therefore, it is necessary to understand how the construction sector is keeping up with the pace of completed projects. The Real estate sector is an important area for the growth of any economy. This sector has been ascended as one of the recognized areas at domestic as well as global level. The term 'Real Estate' is defined as property which includes buildings or structures, property over it. It can also include business houses like residential buildings, commercial offices, theatres, hotels and restaurants, industrial shops like retail shops, factories, and government buildings. The core objective of every industry is to achieve success [40]. Real estate projects generally consider successful while it's far finished scheduled time, within finances, a proper plan, good quality, and customer satisfaction [41]. Project success is depending on project management strategy and manager's leadership skills, customer satisfaction, profitability [42].

\subsection{Project success: An overview}

Defining project success is an exclusive theme. The topic may be more complex in the context of the construction industry. The success of the project has a direct effect on the organization's goodwill. There are standard indicators of project success by which project success or failure can be estimated, and aspects of success contribute to organizational structures that directly or indirectly lead to project or business success [43]. The construction project is generally considered successful when it completes a time, a clearly defined budget, and customer satisfaction [36]. The project achievement is measured in phrases of achieving project goals, projects completed within budget, and with the performance of the organization [44]. Some Researchers considered the scope, time, and cost criteria to be the reason for the success of the project, which was known as the triple iron triangle [45, 46]. In most studies, time, budget, and value-related factors are considered to be the most significant in evaluating the performance of the organization. These criteria are called "the iron triangle" [16, 35, 47].

\subsection{The iron triangle}

According to White and Fortune [20] a real estate projects are generally recognized as successful when it is accomplished within budget, on time, without cost overruns [33]. Time is representing the available time to deliver and completion of a 
business task, the cost is representing the quantity of finance and available assets and the quality of the project is representing the capability to perform satisfactorily [48]. Most of the studies were carried out to determine the "Iron triangle" (Figure 1).

\section{Iron triangle}

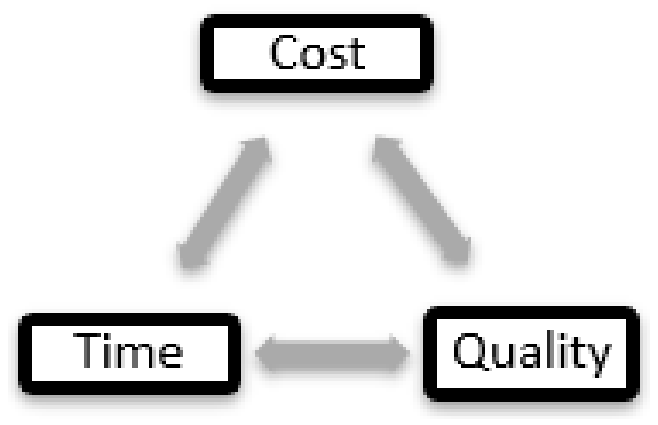

Figure 1. Iron triangle

\section{LITERATURE REVIEW}

The success or failure of a project is measured by the success criteria. The factors that make up the success criteria are usually referred to as key performance indicators $[31,35$, 49]. Time, cost, and quality are three main factors for the success of every project $[31,35,50-53]$. The majority of the studies in consideration to measuring performance areas were based on time, cost, and quality [11, 31, 54-62]. But few studies have focused on the impact of other crucial factors such as customer satisfaction, budget, schedule, and project manager competence $[11,12,18,19,27]$ on the project outcomes. Ingle et al. [12] investigated the customer relation, safety, schedule, cost, quality, productivity, finance, communication and collaboration, the environment and stakeholder satisfaction in this regard. According to Moradi et al. [63], the ability of project managers is of utmost importance for collaborative construction projects. Scheduling is one of the driving factors in the success of the construction project because it guides about when and where to do the work [64, 65].

According to Gemünden et al. [66], project success is measured by time, internal and external factors, budget, and quality. These factors, along with the Iron triangle are also very necessary to make a project successful [67]. However, according to the review of relevant literature, it has been noticed that many researchers have contended with the customs of plan success that emphasizes time, budget, and quality of the project, but many other factors hold a significant place in the project success $[67,68]$. Moreover, five categories were identified by Ahadzie [62]: Internal and external environment related factors, customer satisfaction, quality, cost, and time-related factors. According to Chan and Chan, [69], the success factors for the project include the safety, functionality, budget, cost, schedule, and quality of the project. The project success was measured [70] through cost, quality, safety [71], schedule, and the customer satisfaction. Project manager's leadership style and skills, coordination with project team members and project manager, availability of the financial resource, client's satisfaction, and project completion on time are very significant factors for project success $[10,18$, $32,57,72,73]$.

\subsection{Background of study}

Project success related research isn't new research in social science studies. Since the 1960 s, numerous researches have been directed to find out the factors that are very essential for achieving the success of projects [35]. In their review, according to Cui et al. [74], the first introduced the concept of "factors of success" was recognized by Ronald Daniel of McKinsey \& Company in 1961 [74]. The "success" word is focused on organizational productivity, time, and budgets. The Key Success factors are summarized as follows; Plan, people, Processes, power, Contingency strategy [75].

\section{METHODOLOGY}

The methodology is a method implemented to achieve our objective. This paper is mainly based on the systematic literature review of the construction project's success.

\subsection{Aim and objectives}

The methodology is a method implemented to achieve our objective. This paper is mainly based on the literature review of the construction project's success. The purpose of this study is to find numerous key performance indicators for measuring real estate project success.

A Systematic literature review was adopted to achieve the research objective. To investigate a review on key performance indicators for measuring real estate project success. A systematic literature review was carried out, applying the guidelines developed [7, 53, 76-79]. The purpose of a systematic literature review faithfully reports the existing body of knowledge of a particular research area and it is a structured protocol. The main objective of a systematic literature review is to identify, evaluate, and synthesize existing research $[7,53]$. The step-by-step procedures used in the review indicated in Table 1.

Firstly identified acceptable search related to the current research, then selected the critical studies and after the selected all critical studies then finally carried out the analysis. The process of data collection used in the review indicated in the Figure 2.

\subsection{Search term and information source database}

Several key performance indicators for measuring project success were recognized through a systematic literature review from reputed journals. The databases such as Emerald, Elsevier, Springer, Research Gate, and Scopus etc. were explored to identify the most relevant papers to have a systematic literature review. The reputed journals list for this purpose is included. The reputed journals list for this purpose is included in Table 2.

A paper with these specific words in the title, abstract, or keyword was considered to meet the need of the research. Furthermore, the search related to this research was limited to the subject areas of social science studies, economics, financial management, business, construction, engineering and management, environment, accounting, [2, 7, 34]. After using various online research databases, 82 publications were received using various keywords, Titles, and abstracts related to this research. 
Table 1. Research protocol

\begin{tabular}{l|l}
\hline Research protocol & Detail description \\
\hline Research online databases & $\begin{array}{l}\text { Searches were performed in Scopus, Emerald Insight, Springer Link (Springer), Science } \\
\text { Direct (Elsevier), Wiley, Taylor and Francis, Research Gate, and Sage, web of science, } \\
\text { IEEE Access }\end{array}$ \\
\hline Keywords & $\begin{array}{l}\text { Real estate, construction sector, building projects, customer satisfaction, success factor, } \\
\text { iron triangle, performance, key performance indicators, budget, project management, } \\
\text { scheduling }\end{array}$ \\
\hline Language & English \\
\hline Search fields & Title, keywords and abstract \\
\hline Publication types & Peer-reviewed \\
\hline Time period & One year \\
\hline Search engine & Google, Google scholar \\
\hline Inclusion criteria & Research studies published from 2021-1982 \\
\hline Exclusion criteria & Informal studies (irrelevant paper excluded) \\
\hline $\begin{array}{l}\text { Document } \\
\text { management }\end{array}$ & Mendeley software, Microsoft Excel software, Zotero Software, and EndNote Software, \\
\hline Subject areas bibliography & $\begin{array}{l}\text { Social science studies, economics, financial management, business, construction, } \\
\text { engineering and management, environment }\end{array}$ \\
\hline
\end{tabular}

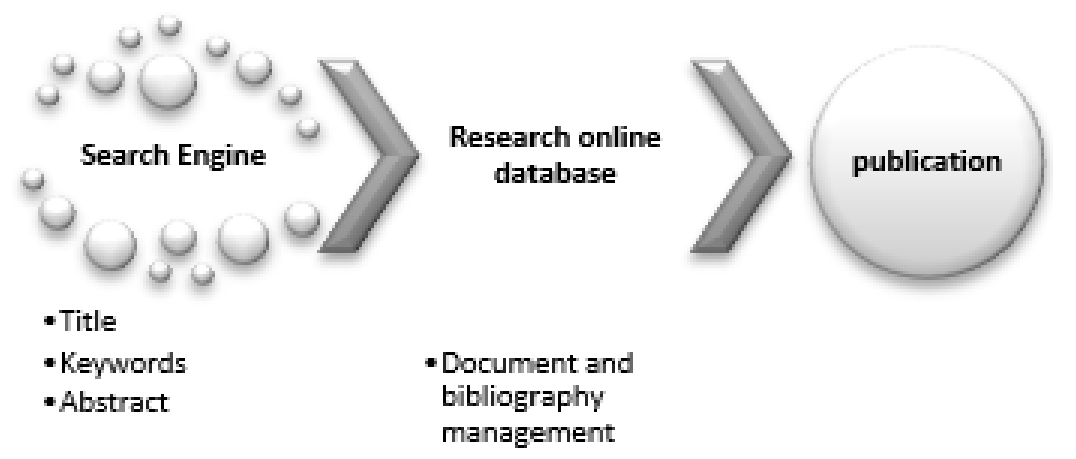

Figure 2. Review process

Table 2. Journal publication details

\begin{tabular}{|c|c|}
\hline Journal Name & Number of publications Year \\
\hline International Journal of Construction Management & 2020,2020 \\
\hline Construction Management and Economics & 2020,1985 \\
\hline International Journal of Business and Management & 2012 \\
\hline Construction Innovation & 2009,2009 \\
\hline International Journal of Sustainable Development and Planning & 2020,2018 \\
\hline Journal of Construction Engineering and Management & $2021,2012,2008,2021,2005$ \\
\hline International Journal of Managing Projects in Business & 2020,2020 \\
\hline Journal of Management in Engineering & $2021,2009,2014,2014,1995$ \\
\hline Project, Programme and Portfolio Management & 2021 \\
\hline International Journal of Project Management & $\begin{array}{c}2005,2005,2007,2010,2004,2018,2017,2005,1999, \\
2013,2008\end{array}$ \\
\hline Contemporary Engineering Sciences & 2011 \\
\hline $\begin{array}{c}\text { International Journal of Sustainable Construction Engineering and } \\
\text { Technology }\end{array}$ & 2020 \\
\hline Cogent Engineering & 2017 \\
\hline Sustainability & 2020 \\
\hline Pakistan Journal of Statistics and Operation Research & 2020 \\
\hline MIT Sloan Management Review & 1982 \\
\hline International Research Journal of Engineering and Technology & 2015 \\
\hline International Journal of Advanced Science and Technology & 2020 \\
\hline International Journal of Information Management & 2020 \\
\hline Project Management Journal & $1988,2005,1987$ \\
\hline $\begin{array}{c}\text { International Journal of Management Science and Business } \\
\text { Administration }\end{array}$ & 2017 \\
\hline Journal of Engineering, Project, and Production Management, & 2020 \\
\hline Decision Support Systems & 2010 \\
\hline Project management handbook & 1997 \\
\hline Project Management Institute & 1987,1992 \\
\hline Journal of Infrastructure Systems & 2021 \\
\hline
\end{tabular}




\begin{tabular}{|c|c|}
\hline Engineering, Construction and Architectural Management & $2020,2004,2004,2020$ \\
\hline Middle-East Journal of Scientific Research & 2011 \\
\hline Journal of Computing in Civil Engineering & 2014,2014 \\
\hline Journal of Facilities Management & 2009 \\
\hline Borld academy of science, engineering and technology & 2010,2008 \\
\hline Buildings & 2021 \\
\hline Robotics and computer-integrated Manufacturing & 2020 \\
\hline IEEE Access & 2021 \\
\hline Journal of Foodservice Business Research & 2021 \\
\hline Journal of Thrombosis and Haemostasis & 2020 \\
\hline International Journal of Information Management & 2016 \\
\hline Journal of Applied Environmental & $2004,2010,2008$ \\
\hline Proceedings papers & 2011 \\
\hline International Conference on Management and Service Science & 2015,2020 \\
\hline Built Environment Project and Asset Management & 2017 \\
\hline USA: John Wiley \& Sons & 2016 \\
\hline Computers \& Industrial Engineering & 2020 \\
\hline International Journal of Engineering Research and General Science & 2004 \\
\hline Benchmarking: an international journal & 2012 \\
\hline NICMAR Journal of Construction Management and Research & 2002 \\
\hline Construction Economics and Building & 1996 \\
\hline European journal of operational research & \\
\hline
\end{tabular}

\subsection{Data collection}

Figure $3[28,29,66]$ shows the number of articles published by year. A total number of " 82 " papers from ABDC journals and other journals and conference papers, including thesis, book chapters, were used to identify all the success factors in the construction sector. The processes of data collection and with journal name and keywords used in the review indicate in Figure 4.

Figure 5 shows the frequency distribution of the articles appeared in various databases considered for the review.

Mendeley software, Microsoft Excel software, Zotero
Software, and EndNote Software, were used to support this screening stage.

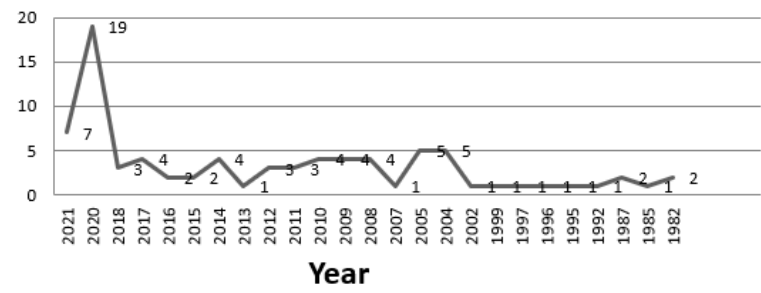

Figure 3. Year wise data

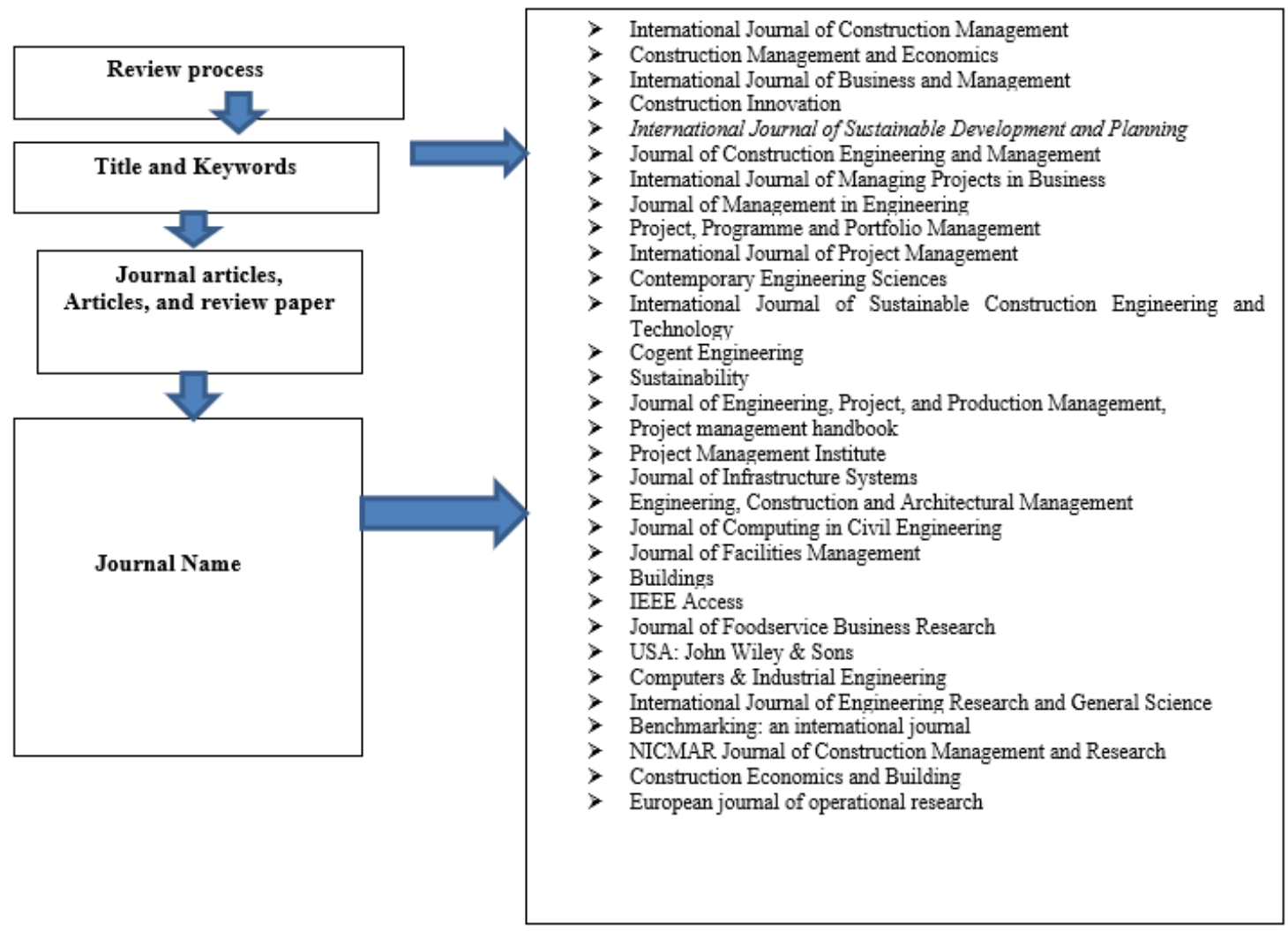

Figure 4. Data collection process 


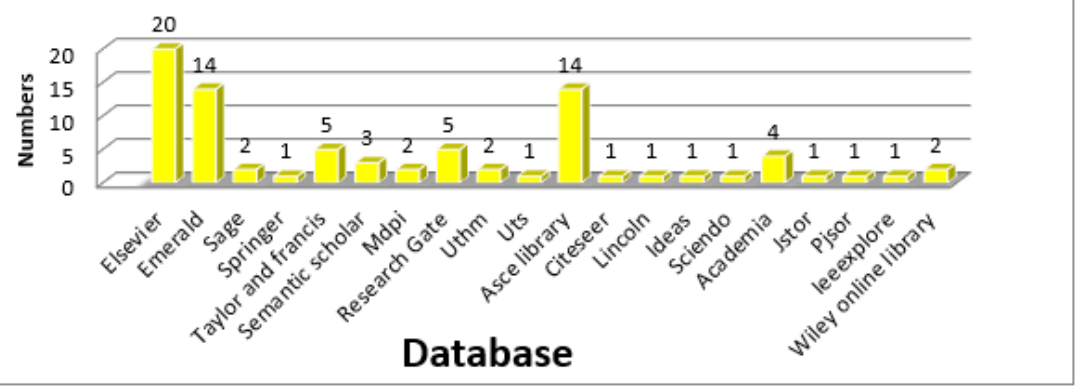

Figure 5. frequency distribution

Table 3. Success factor

\begin{tabular}{|c|c|c|c|c|c|c|c|c|c|c|c|c|c|c|c|c|}
\hline $\begin{array}{l}\text { Researcher/Year } \rightarrow \\
\text { Success Factor } \downarrow\end{array}$ & 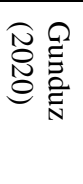 & 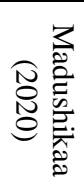 & 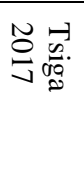 & 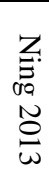 & 象 & 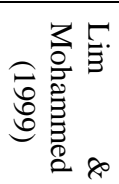 & 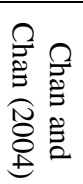 & 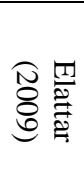 & $\begin{array}{l}\tilde{2} \\
0 \\
0 \\
0 \\
0 \\
0 \\
0 \\
0\end{array}$ & 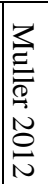 & 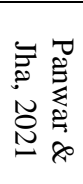 & 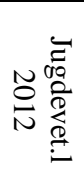 & N & $\begin{array}{l}\text { Q } \\
\text { है } \\
0 \\
\text { ĩ } \\
\text { N } \\
0\end{array}$ & 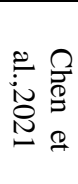 & $\stackrel{-1}{\stackrel{0}{0}}$ \\
\hline Cost & $\sqrt{ }$ & & & $\sqrt{ }$ & $\sqrt{ }$ & $\sqrt{ }$ & $\sqrt{ }$ & & & & $\sqrt{ }$ & $\sqrt{ }$ & $\sqrt{ }$ & $\sqrt{ }$ & & 10 \\
\hline Schedule & $\sqrt{ }$ & & & $\sqrt{ }$ & & & & $\sqrt{ }$ & $\sqrt{ }$ & & & & & & $\sqrt{ }$ & 05 \\
\hline Project Quality & & & & $\sqrt{ }$ & $\sqrt{ }$ & $\sqrt{ }$ & $\sqrt{ }$ & $\sqrt{ }$ & & $\sqrt{ }$ & $\sqrt{ }$ & & $\sqrt{ }$ & $\sqrt{ }$ & & 09 \\
\hline $\begin{array}{l}\text { Customer } \\
\text { Satisfaction }\end{array}$ & $\sqrt{ }$ & $\sqrt{ }$ & & $\sqrt{ }$ & & $\sqrt{ }$ & & $\sqrt{ }$ & & $\sqrt{ }$ & & & & & & 06 \\
\hline Time & $\sqrt{ }$ & & & & $\sqrt{ }$ & $\sqrt{ }$ & $\sqrt{ }$ & & & & $\sqrt{ }$ & $\sqrt{ }$ & $\sqrt{ }$ & $\sqrt{ }$ & & 08 \\
\hline Budget, & $\sqrt{ }$ & $\sqrt{ }$ & & & & & & $\sqrt{ }$ & & & & & & & & 03 \\
\hline $\begin{array}{l}\text { Project Manager } \\
\text { Competence }\end{array}$ & $\sqrt{ }$ & $\sqrt{ }$ & $\sqrt{ }$ & & & & & & $\sqrt{ }$ & & & & & & & 04 \\
\hline
\end{tabular}

Furthermore, the search was limited to the subject areas of social sciences, economics, financial management, business, accounting, construction engineering and management, environment, and decision sciences with publications such as research articles, journals, and review articles. The findings from the extensive literature were assessed and determined on the criteria based on the level of publication, author, and material. The articles for review gathered from various journals, research papers, books, thesis, reports, articles, libraries, websites, etc. to gather relevant information for this study. The period for the search of papers for this review was selected from 1982 to 2021.

The work of the Real Estate Sector is project-oriented. A project is the main part of all activities to fulfill a specific objective. Project management includes project planning, monitoring, and control [73]. The iron triangle related success factor remains the major elements of every task [80]. Table 3 shows the list of success factors taken from reputed Journals through literature reviews.

In the traditional era, an iron triangle was considered an important aspect of the success of the task. The iron triangle was considered an important aspect to plan and manage a successful project. But other criteria were not given much attention to the organization. Customer satisfaction, budget, schedule, and project manager competence are also important parameters of a successful project [81].

The most studies were carried out to the "Iron triangle". The factors of all related to the iron triangle shown in Table 4. But in the present era, many authors suggested that customer satisfaction about the project also be taken into attention [82]. Customer satisfaction can be viewed as a measurement tool for construction project success. If the end-product does not meet customers' expectations, end-users will not be happy [35]. A project does not succeed without customer satisfaction.
Customer satisfaction is an essential technique of evaluating the performance of projects along with the traditional era iron triangle. There have been many studies on the Iron triangle.

Table 4. Iron triangle factor

\begin{tabular}{|c|c|}
\hline \multirow{4}{*}{} & Gunduz (2020) [28] \\
\cline { 2 - 2 } & Kerzner (2017) [47] \\
\cline { 2 - 2 } & Safaei. (2020) [58] \\
\cline { 2 - 2 } COST & Atkinson (1999) [71] \\
\cline { 2 - 2 } TIME & El-Rayes \& Kandil (2005) [8] \\
\cline { 2 - 2 } QUALTY & Ireland (1985) [82] \\
\cline { 2 - 2 } & Babu et al. (1996) [33] \\
\cline { 2 - 2 } & Shankar et al. (2011) [83] \\
\cline { 2 - 2 } & Collins (2004) [73] \\
\cline { 2 - 2 } & Lim and Mohammed (1999) [84] \\
\cline { 2 - 2 } & Chan and Chan (2004) [85] \\
\cline { 2 - 2 } & Mohamma dipour \& Sadjadi, (2016) [86] \\
\hline
\end{tabular}

Customer satisfaction is often allied with performance. Many customers are often dissatisfied with the quality of the project and the service quality. Project performance and customer satisfaction are very closely related. Because when the customer is satisfied with the quality of the project, the organization will get more profit [12]. Customer satisfaction is measured by the distribution of services and the quality of projects that meet customer expectations $[12,64]$. Customer satisfaction is based on understanding customer needs [12]. Thus, customer expectations play a vital role in estimating performance. The factors related to customer satisfaction are shown in Table 5.

Customer satisfaction is associated with many characteristics such as Location, Transportation and banking facilities, Living facilities, Co-operation Site supervision and subcontracting Communication, and Environment and safety 
at work.

This research is exploring additional project success factors, which are helping various ongoing construction projects. With the help of these factors, risks can be reduced and it will also help in the success of the project. Therefore, this research will seek toward classifying the CSF and these CSF is lead to project success and this research will contribute to filling this gap that how successful the project can be made from combinations of common and superior factors for the project success.

Table 5. Customer satisfaction

\begin{tabular}{|c|c|c|}
\hline \multirow{4}{*}{\multicolumn{2}{|c|}{ 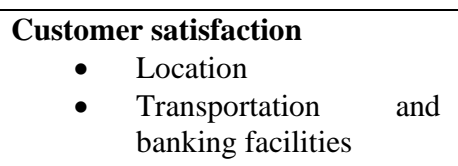 }} & Ingle et \\
\hline & & Oppong et al. (2 \\
\hline & & Alshihre et al. (2 \\
\hline & & 38] \\
\hline \multirow{5}{*}{\multicolumn{2}{|c|}{$\begin{array}{lll}\text { - } & \text { Living facilities } \\
\text { - } & \text { Co-operation } \\
& \text { supervision } \\
& \text { subcontracting and } \\
\text { - } & \text { Communication } \\
\text { - } & \text { Environment and safety } \\
& \text { at work }\end{array}$}} & 2016) \\
\hline & & Rashvand et al. (2014) [41] \\
\hline & & (2013) [90] \\
\hline & & \\
\hline & & ] [2009) (4) \\
\hline
\end{tabular}

\section{DISCUSSION AND CONCLUSION}

Some project plans did not include all of the important aspects for the success of the project, but some researchers identified additional critical elements. Real estate projects are generally considered successful when the project is finished on time, proper schedule, good quality, within budget, and customer happiness [38]. A project must meet the expectation of the users regarding the quality performance to become successful. The level of success and performance in carrying out construction, project development activities will depend heavily on customer satisfaction, quality, time, cost, budget, project management skills, and project schedule. The present review reveals that there are several commons as well as distinctive factors highlighted by the researchers in this field. From an extensive review of the literature, the iron triangle is the most vital aspect of project success. The study reveals that most of the previous research considered the three above mentioned factors, but a few studies have taken the other success factors such as budget, schedule, client satisfaction, and project manager competence. So there is a dire need to explore additional determinants as the real estate project success is influenced by several other variables. The findings suggest that traditional project indicators of construction projects are iron triangles and that these indicators are not sufficient to measure performance. Other performance indicators such as customer satisfaction, budget, manager qualification and schedule are becoming important. The current paper will help the project managers in understanding the vital determinants of project success so that these can be considered while executing the existing and new real estate development projects.

\section{ACKNOWLEDGMENT}

AR would like to acknowledge the University Grant Commission (UGC), New Delhi, for providing SRF under grant number 201516-RGNF-2015-17-SC-HAR-19226.

\section{REFERENCES}

[1] Ahn, Y.H., Pearce, A.R. (2013). Green luxury: A case study of two green hotels. Journal of Green Building, 8(1): 90119. https://doi.org/10.3992/jgb.8.1.90

[2] Hay, C.R., Nissen, F., Pipe, S.W. (2021). Mortality in congenital hemophilia A-a systematic literature review. Journal of Thrombosis and Haemostasis, 19(S1): 6-20. https://doi.org/10.1111/jth.15189

[3] Rejeb, A., Rejeb, K., Keogh, J.G. (2021). Enablers of augmented reality in the food supply chain: A systematic literature review. Journal of Foodservice Business Research, 24(4): https://doi.org/10.1080/15378020.2020.1859973

[4] Kärnä, S., Junnonen, J.M., Sorvala, V.M. (2009). Modeling structure of customer satisfaction with construction. Journal of Facilities Management, 7(2): 111-127. https://doi.org/10.1108/14725960910952505

[5] Shan, R.L., Cai, W.L., Wang, Y.B., Li, D.G. (2012). Research on goal-setting method of rock drivage based on the balance among period, cost and quality. J Coal Sci. Eng China, 18(2): 218-224. https://doi.org/10.1007/s12404-012-0220-y

[6] Adebiyi, R.T., Babalola, O., Amuda-yusuf, G., Rasheed, S.A., Olowa, T.O. (2020). Effect of knowledge and compliance of health and safety information on construction sites workers' safety in Nigeria. International Journal of Safety and Security Engineering, 10(2): 269-277. https://doi.org/10.18280/ijsse.100215

[7] Durdyev, S., Omarov, M., Ismail, S. (2017). Causes of delay in residential construction projects in Cambodia. Cogent Engineering, 4(1): 129111. https://doi.org/10.1080/23311916.2017.1291117

[8] El-Rayes, K., Kandil, A. (2005). Time-cost-quality tradeoff analysis for highway construction. Journal of Construction Engineering and Management, 131(4): 477-486. 9364(2005)131:4(477)

[9] Shenhar, A.J., Dvir, D., Levy, O., Maltz, A.C. (2001). Project success: A multidimensional strategic concept. Long Range Planning, 34(6): 699-725. https://doi.org/10.1016/S0024-6301(01)00097-8

[10] Heravi, G., Faeghi, S. (2014). Group decision making for stochastic optimization of time, cost, and quality in construction projects. Journal of Computing in Civil Engineering, 28(2): 275-283. https://doi.org/10.1061/(ASCE)CP.1943-5487.0000264

[11] Rani, A., Singh, R. (2020). Factors affecting real estate project success: A systematic review and future agenda. International Journal of Advanced Science and Technology, 29(11s): 1006-1016.

[12] Iranmanesh, M. (2017). The impacts of environmental practice characteristics on its implementation in construction project. Procedia Environmental Sciences, 37:

549-555. https://doi.org/10.1016/j.proenv.2017.03.040

[13] Zwikael, O., Shimizu, K., Globerson, S. (2005). Cultural differences in project management capabilities: A field study. International Journal of Project Management, 23(6): $454-$ 462.https://doi.org/10.1016/j.ijproman.2005.04.003

[14] Angus, G.Y., Flett, P.D., Bowers, J.A. (2005). Developing a value-centred proposal for assessing project success. International Journal of Project 
Management,

23(6):

428-436

https://doi.org/10.1016/j.ijproman.2005.01.008

[15] Kang Y., O'Brien W.J., Thomas, S., Chapman, R.E. (2008). Impact of information technologies on performance: cross study comparison. Journal of Construction Engineering and Management, 34(11): 852-863. https://doi.org/10.1061/(ASCE)07339364(2008)134:11(852)

[16] Atkinson, R. (2000). Narratives of policy: The construction of urban problems and urban policy in the official discourse of British government 1968-1998. Critical Social Policy, 20(2): 211-232. https://doi.org/10.1177\%2F026101830002000202

[17] Panwar, A., Jha, K.N. (2021). Integrating quality and safety in construction scheduling time-cost trade-off model. Journal of Construction Engineering and Management, 147(2):

04020160 https://doi.org/10.1061/(ASCE)CO.1943-7862.0001979

[18] Mlinga, R.S., Wells, J. (2002). Collaboration between formal and informal enterprises in the construction sector in Tanzania. Habitat International, 26(2): 269-280. https://doi.org/10.1016/S0197-3975(01)00048-0

[19] Tabish, S.Z.S., Jha, K.N. (2018). Beyond the iron triangle in public construction projects. Journal of Construction Engineering and Management, 144(8): 04018067. https://doi.org/10.1061/(ASCE)CO.19437862.0001517

[20] Wu, G., Li, H., Wu, C., Hu, Z. (2020). How different strengths of ties impact project performance in megaprojects: The mediating role of trust. International Journal of Managing Projects in Business, 13(4): 889912. https://doi.org/10.1108/IJMPB-09-2019-0220

[21] Malacarne, G., Toller, G., Marcher, C., Riedl, M., Matt, D.T. (2018). Investigating benefits and criticisms of BIM for construction scheduling in Smes: An Italian case study. International Journal of Sustainable Development and Planning, 13(1): 139-150. https://doi.org/10.2495/SDP-V13-N1-139-150

[22] Pirotti, A., Keshavarzsaleh, A., Rahim, F.M., Zakaria, N. (2020). Effective factors on project success in malaysian construction industry. Journal of Engineering, Project, and Production Management, 10(1): 1-10. https://doi.org/10.2478/jeppm-2020-0001

[23] Ogunrinde, O., Nnaji, C., Amirkhanian, A. (2021). Developing automation adoption readiness index for quality management focused on highway construction. Journal of Infrastructure Systems, 27(1): 04020049. https://doi.org/10.1061/(ASCE)IS.1943-555X.0000595

[24] Banihashemi, S.A., Khalilzadeh, M. (2020). Time-costquality-environmental impact trade-off resourceconstrained project scheduling problem with DEA approach. Engineering, Construction and Architectural Management, 28(7): https://doi.org/10.1108/ECAM-05-2020-0350

[25] Castro, M.S., Bahli, B., Barcaui, A., Figueiredo, R. (2020). Does one project success measure fit all? An empirical investigation of Brazilian projects. International Journal of Managing Projects in Business, 14(3): 788-805. https://doi.org/10.1108/IJMPB-012020-0028

[26] Bowen, P.A., Cattel, K.S., Hall, K.A., Edwards, P.J., Pearl, R.G. (2002). Perceptions of time, cost, and quality management on building projects. Construction Economics and Building, 2(2): 48-56.
https://doi.org/10.5130/AJCEB.v2i2.2900

[27] Attalla, M., Hegazy, T. (2003). Predicting cost deviation in reconstruction projects: Artificial neural networks versus regression. Journal of Construction Engineering and Management, 129(4): 405-411. https://doi.org/10.1061/(ASCE)07339364(2003)129:4(4 05)

[28] Gunduz, M., Almuajebh, M. (2020). Critical success factors for sustainable construction project management. Sustainability, 12(5): 1990. https://doi.org/10.3390/su12051990

[29] Kärnä, S., Sorvala, V.M., Junnonen, J.M. (2009). Classifying and clustering construction projects by customer satisfaction. Facilities, 27(9/10): 387-398. https://doi.org/10.1108/02632770910969621

[30] Yeung, J.F.Y., Chan, A.P.C., Chan, D.W.M. (2009). Developing a performance index for relationship-based construction projects in Australia: Delphi study. Journal of Management in Engineering, 25(2): 59-68. https://doi.org/10.1061/(ASCE)0742597X(2009)25:2(59)

[31] Han, W.S., Yusof, A.M., Ismail, S., Aun, N.C. (2012). Reviewing the notions of construction project success. International Journal of Business and Management, 7(1): 90. https://doi.org/10.5539/ijbm.v7n1p90

[32] Rockart, J.F. (1982). The changing role of the information system executive: A critical success factor perspective. MIT Sloan Management Review, 23(3): 313. https://doi.org/10.2307/248989

[33] Zahari, R.M.A.S.M., Zin, N.M.Y.S.M. (2017). Small firm performance: An empirical analysis in Malaysian housing construction industry Rosman Mahmood Ahmad Suffian Mohd Zahari Najihah Marha Yaacob Sakinah Mat Zin. International Journal of Housing Markets and Analysis, 10(1): 50-65.

[34] Jenkins, P. (2000). Urban management, urban poverty and urban governance: Planning and land management in Maputo. Environment and Urbanization, 12(1): 137-152. https://doi.org/10.1177\%2F095624780001200110

[35] Toor, S.U.R., Ogunlana, S.O. (2009). Construction professionals' perception of critical success factors for large-scale construction projects. Construction Innovation, $9(2)$ : 149-167. https://doi.org/10.1108/14714170910950803

[36] AlAmeri, A., Rahman, I.A., Nasaruddin, N.A.N. (2020). Ranking of factors causing construction project changes in UAE mega construction projects. International Journal of Sustainable Construction Engineering and Technology, 11(1): 1-6. https://doi.org/10.30880/ijscet.2020.11.01.001

[37] Babu, A.J.G., Suresh, N. (1996). Project management with time, cost, and quality considerations. European Journal of Operational Research, 88(2): 320-327. https://doi.org/10.1016/0377-2217(94)00202-9

[38] Alzahrani, J., Emsley, M. (2013). The impact of contractors' attributes on construction project success: A post-construction evaluation. International Journal of Project Management, 31(2): 313-322. https://doi.org/10.1016/j.ijproman.2012.06.006

[39] Nguyen, L.D., Ogunlana, S.O., Lan, D.T.X. (2004). A study on project success factors in large construction projects in Vietnam. Engineering, Construction, and Architectural Management, 11(6): 404-413. https://doi.org/10.1108/09699980410570166 
[40] Sirisomboonsuk, P., Gu, V.C., Cao, R.Q., Burns, J.R. (2018). Relationships between project governance and information technology governance and their impact on project performance. International Journal of Project Management, $36(2)$ : https://doi.org/10.1016/j.ijproman.2017.10.003

[41] Nguyen, T.P., Chileshe, N. (2015). Revisiting the construction project failure factors in Vietnam. Built Environment Project and Asset Management, 5(4): 398416. https://doi.org/10.1108/BEPAM-10-2013-0042

[42] Ogunlana, S.O. (2010). Beyond the 'iron triangle': Stakeholder perception of key performance indicators (KPIs) for large-scale public sector development projects. International Journal of Project Management, 28(3): 228236. https://doi.org/10.1016/j.ijproman.2009.05.005

[43] Viswanathan, S.K., Jha, K.N. (2020). Critical risk factors in international construction projects: An Indian perspective. Engineering, Construction and Architectural Management, 27(5): 1169-1190. https://doi.org/10.1108/ECAM-04-2019-0220

[44] Rashvand, P., Majid, M.Z.A. (2014). Critical criteria on client and customer satisfaction for the issue of performance measurement. Journal of Management in Engineering, 30(1):

$10-18$ https://doi.org/10.1061/(ASCE)ME.1943-5479.0000183

[45] Sirisomboonsuk, P., Gu, V.C., Cao, R.Q., Burns, J.R. (2018). Relationships between project governance and information technology governance and their impact on project performance. International Journal of Project Management, 36(2): 287-300. https://doi.org/10.1016/j.ijproman.2017.10.003

[46] Viswanathan, S.K., Tripathi, K.K., Jha, K.N. (2020). Influence of risk mitigation measures on international construction project success criteria-a survey of Indian experiences. Construction Management and Economics, 38(3): https://doi.org/10.1080/01446193.2019.1577987

[47] Kerzner, H. (2017). Project Management: A Systems Approach to Planning, Scheduling, and Controlling. USA: John Wiley \& Sons.

[48] Jha, K.N., Iyer, K.C. (2007). Commitment, coordination, competence and the iron triangle. International Journal of Project Management, 25(5): 527-540. https://doi.org/10.1016/j.ijproman.2006.11.009

[49] Ingle, P.V., Mahesh, G. (2020). Construction project performance areas for Indian construction projects. International Journal of Construction Management, 1-12. https://doi.org/10.1080/15623599.2020.1721177

[50] Haverila, M., Haverila, K.C., Twyford, J.C. (2020) Critical variables and constructs in the context of project management: importance-performance analysis. International Journal of Managing Projects in Business, 14(4): 836-864. https://doi.org/10.1108/IJMPB-022020-0071

[51] Nilsson, L., Johnson, M.D., Gustafsson, A. (2001). The impact of quality practices on customer satisfaction and business results: Product versus service organizations. Journal of Quality Management, 6(1): 5-27. https://doi.org/10.1016/S1084-8568(01)00026-8

[52] Zhang, L., Du, J., Zhang, S. (2014). Solution to the timecost-quality trade-off problem in construction projects based on immune genetic particle swarm optimization. Journal of Management in Engineering, 30(2): 163-172. https://doi.org/10.1061/(ASCE)ME.1943-5479.0000189
[53] Rahman, A., Alzubi, Y. (2015). Exploring key contractor factors influencing client satisfaction level in dealing with construction project: An empirical study in Jordan. International Journal of Academic Research in Business and Social Sciences, 5(12): 109-126. https://doi.org/10.6007/IJARBSS/v5-i12/1935

[54] Pinto, J.K., Slevin, D.P. (1989). Critical success factors in R\&D projects. Research-Technology Management, 32(1): 31-35. https://doi.org/10.1080/08956308.1989.11670572

[55] Oppong, G.D., Chan, A.P., Dansoh, A. (2017). A review of stakeholder management performance attributes in construction projects. International Journal of Project Management, 35(6): 1037-1051. https://doi.org/10.1016/j.ijproman.2017.04.015

[56] Belout, A., Gauvreau, C. (2004). Factors influencing the project success: The impact of human resource management. International Journal of Project Management, 22: 1-11. https://doi.org/10.1016/S02637863(03)00003-6

[57] Lauras, M., Marques, G., Gourc, D. (2010). Towards a multi-dimensional project performance measurement system. Decision Support Systems, 48(2): 342-353. https://doi.org/10.1016/j.dss.2009.09.002

[58] Safaei, M. (2020). Sustainable survival pyramid model to balance four factors of cost, quality, risk, and time limitation in project management under uncertainty. Pakistan Journal of Statistics and Operation Research, 16(2): 287-294. https://doi.org/10.18187/pjsor.v16i2.3203

[59] Forcada, N., Casals, M., Gangolells, M., Roca, X., Fuertes, A. (2011). Experiences of success in industrial plants projects. RevistaIngeniería de Construcción, 23(2) 82-93. http://dx.doi.org/10.4067/S071850732008000200003

[60] Yang, X., Lin, Y. (2011). Study of residential real estate based on the customer satisfaction index. In 2011 International Conference on Management and Service Science, pp.

$1-4$. https://doi.org/10.1109/ICMSS.2011.5998224

[61] Rezaian, A. (2011). Time-cost-quality-risk of construction and development projects or investment. Middle-East Journal of Scientific Research, 10(2): 218223. https://doi.org/10.6007/IJARBSS/v5-i12/1935

[62] Ahadzie, D.K., Proverbs, D.G., Olomolaiye, P.O. (2008). Critical success criteria for mass house building projects in developing countries. International Journal of Project Management, 26(6): 675-687. https://doi.org/10.1016/j.ijproman.2007.09.006

[63] Moradi, S., Kähkönen, K., Klakegg, O.J., Aaltonen, K. (2021). A competency model for the selection and performance improvement of project managers in collaborative construction projects: Behavioral studies in Norway and Finland. Buildings, 11(1): 4. https://doi.org/10.3390/buildings11010004

[64] Chancellor, W., Lu, W. (2016). A regional and provincial productivity analysis of the Chinese construction industry: 1995 to 2012. Journal of Construction Engineering and Management, 142(11): 05016013. https://doi.org/10.1061/(ASCE)CO.1943-7862.0001177

[65] Makarevich, S., Pavlov, S., Terleev, V. (2015). Redevelopment project of shuvalovsky park. In Applied Mechanics and Materials, 725: 1158-1164. https://doi.org/10.4028/www.scientific.net/AMM.725- 
726.1158

[66] Gemünden, H.G., Salomo, S., Krieger, A. (2005). The influence of project autonomy on project success. International Journal of Project Management, 23(5): 366373. https://doi.org/10.1016/j.ijproman.2005.03.004

[67] Chen, L., Lu, Q., Li, S., He, W., Yang, J. (2021). Bayesian monte Carlo simulation driven approach for construction schedule risk inference. Journal of Management in Engineering, 37(2): 04020115. https://doi.org/10.1061/(ASCE)ME.1943-5479.0000884

[68] Ahmed, S.M., Kangari, R. (1995). Analysis of clientsatisfaction factors in the construction industry. Journal of Management in Engineering, 11(2): 36-44. https://doi.org/10.1061/(ASCE)0742597X(1995)11:2(36)

[69] Chan, A.P., Owusu, E.K. (2017). Corruption forms in the construction industry: Literature review. Journal of Construction Engineering and Management, 143(8): 04017057. https://doi.org/10.1061/(ASCE)CO.19437862.0001353

[70] Cline, K.M., Clement, V., Rock-Klotz, J., Kash, B.A., Steel, C., Miller, T.R. (2020). Improving the cost, quality, and safety of perioperative care: A systematic review of the literature on implementation of the perioperative surgical home. Journal of Clinical Anesthesia, 63: 109760.

[71] Atkinson, R. (1999). Project management: cost, time and quality, two best guesses and a phenomenon, it's time to accept other success criteria. International Journal of Project Management, 17(6): 337-42. https://doi.org/10.1016/S0263-7863(98)00069-6

[72] He, Q., Wang, T., Chan, A.P., Xu, J. (2021). Developing a list of key performance Indictors for benchmarking the success of construction megaprojects. Journal of Construction Engineering and Management, 147(2): 04020164. https://doi.org/10.1061/(ASCE)CO.19437862.0001957

[73] Baccarini, D., Collins, A. (2003). Critical success factors for projects. In Proceedings of the 17th ANZAM Conference. https://doi.org/10.1177\%2F875697289903000405

[74] Cui, Y., Kara, S., Chan, K.C. (2020). Manufacturing big data ecosystem: A systematic literature review. Robotics and Computer-Integrated Manufacturing, 62: 101861. https://doi.org/10.1016/j.rcim.2019.101861

[75] Mohammadipour, F., Sadjadi, S. (2016). Project costquality-risk tradeoff analysis in a time-constrained problem. Computers \& Industrial Engineering, 95(1): 111-121. https://doi.org/10.1016/j.cie.2016.02.025

[76] Durdyev, S. (2020). Review of construction journals on causes of project cost overruns. Engineering, Construction, and Architectural Management, 28(4): 1241-1260. https://doi.org/10.1108/ECAM-02-20200137

[77] Ali, O., Ally, M., Dwivedi, Y. (2020). The state of play of blockchain technology in the financial services sector: A systematic literature review. International Journal of Information Management, 54: 102199. https://doi.org/10.1016/j.ijinfomgt.2020.102199

[78] Al-Tashi, Q., Abdulkadir, S.J., Rais, H.M., Mirjalili, S., Alhussian, H. (2020). Approaches to multi-objective feature selection: A systematic literature review. IEEE
Access, 8: 125076-125096. https://doi.org/10.1109/ACCESS.2020.3007291

[79] Isikyildiz, S., Akcay, C. (2020). Multi-objective optimization of time-cost-quality in construction projects using genetic algorithm. Revista de la construcción, 19(3), 335-346. http://dx.doi.org/10.7764/rdlc.19.3.335

[80] Abd El Razek, R.H., Diab, A.M., Hafez, S.M., Aziz, R.F. (2010). Time-cost-quality trade-off software by using simplified genetic algorithm for typical repetitive construction projects. Engineering and Technology, 61(1): 312-321. https://doi.org/10.5281/zenodo.1085617

[81] Bryde, D.J., Brown, D. (2005). The influence of a project performance measurement system on the success of a contract for maintaining motorways and trunk roads. Project Management Journal, 35(4): 57-65. https://doi.org/10.1177\%2F875697280403500407

[82] Ireland, V. (1985). The role of managerial actions in the cost, time, and quality performance of high-rise commercial building projects. Construction Management and Economics, 3(1): 59-87. https://doi.org/10.1080/0144619850000000

[83] Shankar, N.R., Raju, M.M.K., Srikanth, G., Bindu, P.H. (2011). Time, cost and quality trade-off analysis in construction of projects. Contemporary Engineering Sciences, 4(6): 289-299.

[84] Lim, C.S., Mohamed, M.Z. (1999). Criteria of project success: an exploratory re-examination. International Journal of Project Management, 17(4): 243-248. https://doi.org/10.1016/S0263-7863(98)00040-4

[85] Chan, A.P., Chan, D.W., Chiang, Y.H., Tang, B.S., Chan, E.H., Ho, K.S. (2004). Exploring critical success factors for partnering in construction projects. Journal of Construction Engineering and Management, 130(2): 188-198. https://doi.org/10.1061/(ASCE)07339364(2004)130:2(188)

[86] Mohammadipour, F., Sadjadi, S.J. (2016). Project costquality-risk tradeoff analysis in a time-constrained problem. Computers \& Industrial Engineering, 95: 111121. https://doi.org/10.1016/j.cie.2016.02.025

[87] Alshihre, F., Chinyio, E., Nzekwe-Excel, C., Daniel, E.I. (2020). Improving clients' satisfaction in construction projects: The case of Saudi Arabia. Built Environment Project and Asset Management, 10(5): 709-723. https://doi.org/10.1108/BEPAM-12-2019-0140

[88] Yang, X., Lin, Y. (2011). Study of residential real estate based on the customer satisfaction index. In 2011 International Conference on Management and Service Science, pp.

$1-4$. https://doi.org/10.1109/ICMSS.2011.5998224

[89] Zahari, A.S.M., Syahirah, S.I., Mahmood, R., Baniamin, R.M.R. (2016). Measuring customer satisfaction on housing projects: An empirical investigation. J. Appl. Environ. Biol. Sci., 6(7S): 7-12.

[90] Sweis, G.J. (2013). Factors affecting time overruns in public construction projects: The case of Jordan. International Journal of Business and Management, 8(23): 120. http://dx.doi.org/10.5539/ijbm.v8n23p120

[91] Yeheyes, M. (2018). The effect of service quality on customer satisfaction in real estate industry: The case of afro-Tsion real estate. Doctoral dissertation, st. Mary's University. http://hdl.handle.net/123456789/4320 